\title{
Improvement of prudential measures of The Bank of Russia under new conditions
}

\author{
$V . V$. Kremleva $^{l, 2}, N . S$. Necheukhina ${ }^{l}$, and O.I. Dudina ${ }^{l}$ \\ ${ }^{1}$ Ural State University of Economics, 620114 Ekaterinburg, Russia, \\ ${ }^{2}$ Dagestan State University of National Economy, 367008 Makhachkala, Russia,
}

\section{Introduction}

The main objective of the Bank of Russia is to maintain the banking system stability, and therefore, eliminate deficiencies in banking regulation and banking supervision in order to suppress attempts to unjustifiably increase assets, protect consumer rights in the financial market, increase the financial stability of credit organizations, and exclude unfair players from the market

Recently many changes have taken place in the banking sector of the Russian Federation. The most significant change is the division of banks into 2 categories depending on the license type: banks with a universal license and banks with a basic license. Each category of banks has to meet different requirements, including regulatory requirements, prudential provisioning, and permitted transactions.

Research objectives are to evaluate the efficiency of the regulator's innovations in terms of developing the banking services market and protecting consumer rights in this market, as well as increasing the banking system stability.

\section{Research methods}

Since 2019, improvement of the banking sector regulation has been ongoing, and new rules have been introduced to create reserves for possible losses from loans, new rules of lending to individuals, and much more, which we will dwell on in more detail.

Changes in banking legislation can be divided into two groups: innovations aimed at increasing the banking sector financial stability and measures aimed at developing the banking services market and protecting consumer rights in this market (Table 1,2,3).

Table 1. Regulator's measures to increase the banking sector financial stability

\begin{tabular}{|c|c|c|}
\hline $\begin{array}{l}\text { Changes in banking } \\
\text { regulation }\end{array}$ & Meaning & Results, consequences \\
\hline $\begin{array}{l}\text { LCR increase for } \\
\text { systematically important } \\
\text { banks since January 1, } 2019 \\
\text { in accordance with the } \\
\text { schedule of "Basel III" } \\
\text { phased implementation } \\
\text { adopted in late 2015 } \\
\end{array}$ & $\begin{array}{l}\text { Minimum acceptable liquidity } \\
\text { coverage ratio (LCR) is } \\
\text { increased from } 90 \% \text { to } 100 \% \text { : } \\
\text { highly liquid assets/ net } \\
\text { expected cash outflows within } \\
30 \text { calendar days (in case of a } \\
\text { stress situation) }\end{array}$ & $\begin{array}{l}\text { "Basel III" implementation } \\
\text { has been completed [5]. } \\
\text { Ensuring short term sufficient } \\
\text { liquidity }\end{array}$ \\
\hline $\begin{array}{l}\text { Schedule has been set for } \\
\text { increasing capital adequacy }\end{array}$ & $\begin{array}{l}\text { Starting from January } 1,2019 \\
\text { the increase was } 1,875 \%, \text { from }\end{array}$ & $\begin{array}{l}\text { The increase should cover } \\
\text { bank losses during financially }\end{array}$ \\
\hline
\end{tabular}




\begin{tabular}{|c|c|c|}
\hline $\begin{array}{l}\text { ratio in accordance with } \\
\text { "Basel III". Capital } \\
\text { adequacy ratio (applies to } \\
\text { all banks with universal } \\
\text { license) is increased } \\
\text { according to the schedule } \\
\text { approved by the Central } \\
\text { Bank }\end{array}$ & $\begin{array}{l}\text { April } 1,2019-2 \%, \text { from July } \\
1,2019-2,125 \% \text {, from } \\
\text { October } 1,2019-2,25 \%, \\
\text { since January } 1,2020-2,5 \% \text {. } \\
\text { It is calculated in percent of } \\
\text { risk-weighted assets }\end{array}$ & $\begin{array}{l}\text { unstable periods. Banks that } \\
\text { do not meet increased capital } \\
\text { adequacy requirements are } \\
\text { limited in their rights to } \\
\text { distribute profits and pay non- } \\
\text { fixed reward to management }\end{array}$ \\
\hline $\begin{array}{l}\text { Systemically important } \\
\text { banks begin to calculate the } \\
\text { maximum single customer } \\
\text { concentration risk or group } \\
\text { of related customers } \\
\text { concentration risk }\end{array}$ & $\begin{array}{l}\text { All credit requirements to a } \\
\text { single borrower (group of } \\
\text { borrowers) without risk- } \\
\text { weighting / fixed capital. }\end{array}$ & $\begin{array}{l}\text { Supervisory requirements to } \\
\text { limit major risks according to } \\
\text { "Basel III" [5] }\end{array}$ \\
\hline $\begin{array}{l}\text { The risk coefficient for } \\
\text { mortgage loans with down } \\
\text { payment of } 10 \% \text { to } 20 \% \\
\text { increases, therefore, the } \\
\text { capital adequacy ratio of } \\
\text { banks with such loans in the } \\
\text { portfolio will drop (Fig. 1) }\end{array}$ & $\begin{array}{l}\text { Risk ratio increases from } 150 \% \\
\text { to } 200 \% \text { for loans granted since } \\
\text { January } 1,2019 \text {. The rule will } \\
\text { be valid only for a period until } \\
\text { the ratio of loan debt to } \\
\text { collateral value exceeds } 80 \% \text {. }\end{array}$ & $\begin{array}{l}\text { 1) Decrease of bank risk on } \\
\text { mortgage loans. Decreased } \\
\text { default risk for mortgage } \\
\text { clients } \\
\text { 2) Banks are less interested in } \\
\text { such borrowers }\end{array}$ \\
\hline
\end{tabular}

The main indicator of the banking sector stability is the capital adequacy ratio (H1). Taking this ratio in consideration, the Bank of Russia can revoke a license or reorganize a bank. In Russia CAR is $8 \%$, and Russia's banks easily fit this norm at the moment, although there has been a slight drop in $\mathrm{H} 1$ due to the tightening of requirements for calculating risk-weighted assets. Table 2 shows the capital adequacy ratio of the banking system before and after the introduction of the measures presented in table 1.

Table 2. Capital adequacy ratio of Russia's banks

\begin{tabular}{|l|l|l|l|l|}
\hline \multirow{2}{*}{ Value of H1.0 } & \multicolumn{2}{|l|}{$\mathbf{1 . 0 1 . 1 8}$} & $\mathbf{1 . 0 2 . 2 0}$ \\
\cline { 2 - 5 } & $\begin{array}{l}\text { Number of } \\
\text { credit } \\
\text { organizations }\end{array}$ & $\begin{array}{l}\text { Share in banking } \\
\text { share assets, \% }\end{array}$ & $\begin{array}{l}\text { Number of } \\
\text { credit } \\
\text { organizations }\end{array}$ & $\begin{array}{l}\text { Share in } \\
\text { banking } \\
\text { sector } \\
\text { assets, \% }\end{array}$ \\
\hline Lower than $8 \%$ & 20 & 6.8 & 10 & 2.4 \\
\hline From $8 \%$ to $10 \%$ & 9 & 15 & 4 & 0.4 \\
\hline From 10\% to 12\% & 36 & 21.5 & 22 & 17.5 \\
\hline From 12\% to 14\% & 64 & 18.1 & 46 & 53.5 \\
\hline $14 \%$ and higher & 420 & 52.1 & 344 & 22.4 \\
\hline Profitable CO & 421 & - & 319 & - \\
\hline Unprofitable CO & 140 & - & 108 & - \\
\hline
\end{tabular}

In general, as of 02.20 .2020 , the capital adequacy ratio in the banking system was $12.5 \%$ with the norm of $8 \%$ (compared with $12.1 \%$ of 01.01 .2018 ). It means that measures to ease prudential supervision in terms of regulations did not lead to deterioration of the result.

Short-term liquidity ratios $\mathrm{H} 26, \mathrm{H} 27$, which are calculated as the ratio of highly liquid assets to expected cash outflows within 30 days as of 01.01 .2019 , were observed by all banks. The norm was $90 \%$ in 2018 , and increased to $100 \%$ in 2019 . Systemically important banks exceeded this ratio, as of 01.01 .2019 . It amounted to $130.5 \%$ (in the range from $98.6 \%$ to $177.7 \%$ ) [2]. What does the LCR coefficient signify? This ratio forces banks to 
have sufficient unencumbered high-quality liquid assets in case an outflow of funds occurs within 30 days as a result of a stress scenario:

- outflow of retail deposits;

- outflow from derivatives (market valuation);

- unsecured financing by non-financial institutions.

The formula for calculating LCR is as follows:

$$
\boldsymbol{L C} \boldsymbol{R}=\frac{\text { High quality liquid assets }}{\text { Net outflow within } 30 \text { days }} \geq \mathbf{1 0 0} \%
$$

Table 3. Regulator's measures to develop the banking services market and protect consumer rights in this market

\begin{tabular}{|c|c|c|}
\hline $\begin{array}{l}\text { Changes in banking } \\
\text { regulation }\end{array}$ & Meaning & Results, consequences \\
\hline $\begin{array}{l}\text { Deposit insurance system } \\
\text { applies to funds of small } \\
\text { enterprises in rubles and } \\
\text { foreign currency placed in } \\
\text { banks of the Russian } \\
\text { Federation }\end{array}$ & $\begin{array}{l}\text { Insurance indemnity is } 100 \% \text { of the } \\
\text { amount of funds in the accounts } \\
\text { (deposits), but not more than } 1.4 \\
\text { million rubles in total in each bank. }\end{array}$ & $\begin{array}{l}\text { Protecting SMEs from } \\
\text { risks }\end{array}$ \\
\hline $\begin{array}{l}\text { Loans to developers as part of } \\
\text { shared construction } \\
\text { development have been } \\
\text { recorded in escrow bank } \\
\text { accounts since July } 2019 \text {. }\end{array}$ & $\begin{array}{l}\text { Escrow account is a bank account } \\
\text { that is opened for depositing } \\
\text { interest holders' money until the } \\
\text { construction is finished }\end{array}$ & $\begin{array}{l}\text { 1) Significant risk } \\
\text { reduction for interest } \\
\text { holders } \\
\text { 2) Development of project } \\
\text { financing in banks }\end{array}$ \\
\hline $\begin{array}{l}\text { SME loans on standard terms } \\
\text { increase from } 5 \text { to } 10 \text { million } \\
\text { rubles, financial situation } \\
\text { being "average" }\end{array}$ & $\begin{array}{l}\text { Loans up to } 10 \text { million rubles can } \\
\text { now be included in a portfolio of } \\
\text { homogeneous loans with standard } \\
\text { terms of granting }\end{array}$ & $\begin{array}{l}\text { A standardized approach } \\
\text { to assessing the risks of } \\
\text { SMEs with a larger } \\
\text { contract amount. A loan } \\
\text { becomes more affordable } \\
\text { even if a borrower's } \\
\text { financial situation is } \\
\text { "average" }\end{array}$ \\
\hline $\begin{array}{l}\text { Reduced asset risk ratio } \\
(75 \%) \text { is applied to SMEs } \\
\text { when calculating capital } \\
\text { adequacy }\end{array}$ & $\begin{array}{l}\text { The maximum amount per single } \\
\text { borrower rises from } 60 \text { million to } \\
70 \text { million, the risk ratio is reduced } \\
\text { from } 100 \% \text { to } 75 \%\end{array}$ & $\begin{array}{l}\text { Ratio H1 allows to } \\
\text { increase lending to SMEs }\end{array}$ \\
\hline $\begin{array}{l}\text { While assessing the } \\
\text { creditworthiness of SMEs, it } \\
\text { is not necessary now to } \\
\text { analyze a company's } \\
\text { operation }\end{array}$ & $\begin{array}{l}\text { Financial situation without } \\
\text { operational analysis can be } \\
\text { recognized as "good" }\end{array}$ & $\begin{array}{l}\text { The volume of reserves } \\
\text { for possible losses from } \\
\text { loans decreases. This } \\
\text { results in } \\
\text { better loan affordability } \\
\text { for SMEs and fewer bank } \\
\text { denials. }\end{array}$ \\
\hline $\begin{array}{l}\text { Requirements for risk } \\
\text { assessment of restructured } \\
\text { and refinanced loans to SMEs } \\
\text { are reduced }\end{array}$ & $\begin{array}{l}\text { Debt service of restructured and } \\
\text { refinanced loans is recognized as } \\
\text { "good" }\end{array}$ & $\begin{array}{l}\text { The volume of reserves } \\
\text { for possible losses from } \\
\text { loans decreases and } \\
\text { affordability of loans to } \\
\text { SMEs increases. }\end{array}$ \\
\hline $\begin{array}{l}\text { SME Corporation guarantees } \\
\text { are taken into account when } \\
\text { assessing the risks of lending } \\
\text { to SMEs }\end{array}$ & SME Corporation guaranteed loans & $\begin{array}{l}\text { Improving affordability of } \\
\text { loans to SMEs and } \\
\text { reducing the number of } \\
\text { bank denials. }\end{array}$ \\
\hline
\end{tabular}


Some liberalization of risk management in lending to small and medium-sized businesses is worth special attention. What can this lead to? Let us look into fundamental indicators that caused liberalization of banking supervision in credit risks of SMEs.

First of all, it is necessary to refer to the statistics on overdue debts and creation of reserves for possible losses from loans to SMEs [2]:

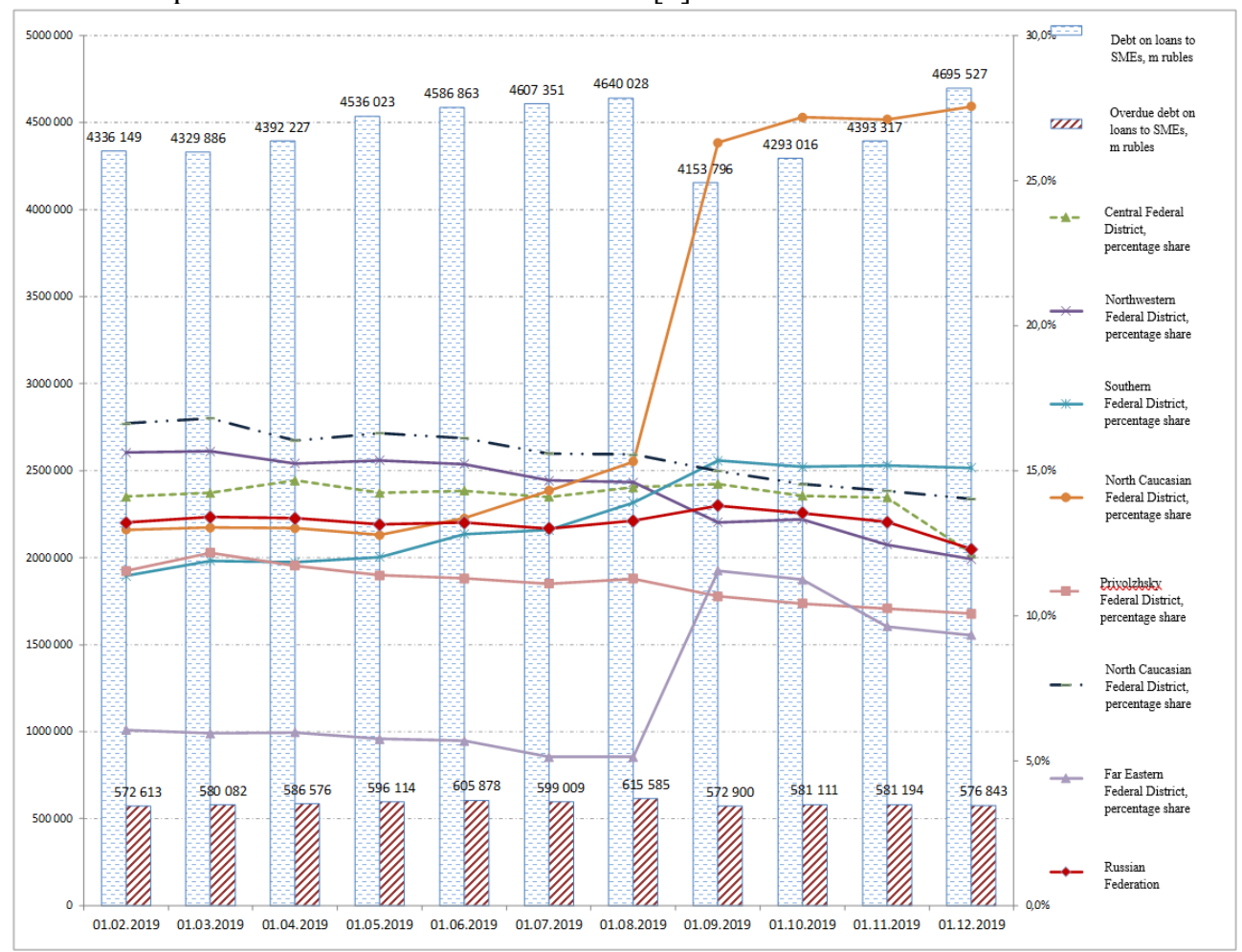

Fig. 1. Debt on loans to small and medium-sized businesses, including loan arrears, million rubles scale on the left, share of overdue debt in the portfolio (scale on the right)

The regulator's decision to ease the risk assessment policy for SMEs is quite reasonable: the share of delinquency in this segment is falling: it was $13.2 \%$ in early 2019 and $12.3 \%$ in late 2019 . Only some regions demonstrate an aggravation of the solvency situation of small and medium-sized borrowers (North-Caucasian Federal District and Far Eastern Federal District), which is associated with regional features.

As for mortgages, we can see some tightening of requirements for assessing these assets risks, in particular loans with a down payment of $<20 \%$. The share of overdue mortgage loans decreased from $1.3 \%$ to $0.9 \%$ starting from early 2018 to early 2019 . However, the amount of granted mortgage loans increased from 1.9 to 2.3 million rubles [3]. In addition, mortgages with a low down payment are one and a half times more likely to default [4]. Although mortgage lending remains the most high-quality segment of lending at the moment, mortgage borrowers are too debt-ridden and besides mortgage borrowers have to repay other loans as well. From the point of view of borrowers and the mortgage market development, there exists a negative effect. Banks are less interested in these borrowers, as it is necessary to create larger reserves for them now.

In 2019 , the regulator took new measures to protect interest holders' property. Since July 2019, developers have to use escrow accounts. Now they will be able to develop construction projects not with interest holders' money, but with their own or credit funds. Holders' money is kept in escrow accounts until they become real estate owners. An 
interest holder, who was a developer's "creditor", is not able to assess the developer's creditworthiness, and the bank responsibility is providing loans and professional assessing of borrowers. The source of the loan is the escrow account itself. Money can be transferred to the account only after the registration of the share agreement in Rosreestr (Federal Service for State Registration, Cadaster and Cartography). The developer can receive payment from the escrow account only after the building is put into operation.

\section{Conclusions}

Changes in banking supervision adopted in 2018-2019 protect the rights of banking services consumers, and also aim at improving the banking sector stability and increasing economic growth.

The following factors support that conclusion:

- Growth of the banking sector liquidity in stress situations (tightening LCR coefficient).

- Reducing default risks on mortgage lending.

- Small and medium-sized businesses development because of greater access to bank loans, as well as the protection of their money in commercial banks.

- Protection of interest holders' rights.

However, with regard to LCR, the introduction of this indicator poses some problems that require further consideration:

- The desire of banks to use liquid securities more actively though this asset has a lower return level

- Reduction of bank securities in banks return.

These problems, in turn, reduce the bank's interest margin, and as a result can lead to an increase in lending rates.

\section{References}

1. Federal Law "On the Central Bank of the Russian Federation (Bank of Russia)" dated 10.07.2002 № 86-FZ

2. Bank of Russia, Report on the development of the Banking sector and banking supervision in 2018, (2019)

3. Mortgage housing loans granted to resident individuals and acquired rights of claim on mortgage housing loans in rubles. www.cbr.ru

4. The Central Bank suggested complicating the issuance of mortgages to loaned borrowers. How new restrictions can affect banks and developers. https://www.rbc.ru/finances/02/12/2019/5de546fb9a794723ae57ed28

5. Monitoring the framework for measuring and controlling major risks. Supervisory structure for measuring and controlling major impacts, March 2013 https://www.bis.org/publ/bcbs246.pdf 